\title{
ARAHAN PENGENDALIAN PEMBANGUNAN KAWASAN CAGAR BUDAYA CANDI TEBING GUNUNG KAWI TAMPAKSIRING KABUPATEN GIANYAR
}

NYOMAN ARTO SUPRAPTO

NRP 3606100055

Dosen Pembimbing

Putu Gde Ariastita, ST, MT

PROGRAM STUDI PERENCANAAN WILAYAH DAN KOTA Fakultas Teknik Sipil dan Perencanaan Institut Teknologi Sepuluh Nopember Surabaya 2010 


\title{
ARAHAN PENGENDALIAN PEMBANGUNAN \\ KAWASAN CAGAR BUDAYA CANDI TEBING GUNUNG KAWI TAMPAKSIRING KABUPATEN GIANYAR
}

\author{
Nyoman Arto Suprapto ${ }^{1)}$; Putu Gede Ariastita ${ }^{2)}$ \\ 1) Mahasiswa S1 Perencanaan Wilayah dan Kota, ITS \\ ${ }^{2)}$ Dosen S1 Perencanaan Wilayah dan Kota, ITS
}

E-mail: artopraph@gmail.com

\begin{abstract}
ABSTRAK
Candi Tebing Gunung Kawi Tampaksiring (GKT) adalah salah satu aset/benda cagar budaya yang terletak di Kabupaten Gianyar. GKT ini memiliki potensi pariwisata yang sangat tinggi (wisata budaya), hal ini terbukti dari besarnya jumlah kunjungan wisatawan ke lokasi ini dari tahun ke tahun. Potensi pariwisata yang besar tersebut membawa dampak positif dan negatif terhadap keberadaan situs GKT. Dampak negatif dari perkembangan pariwisata tersebut adalah adanya intervensi terhadap aktivias GKT. Sehingga penelitian ini bertujuan untuk merumuskan arahan pemanfaatan lahan kawasan GKT.

Metode analisa yang digunakan dalam penelitian ini adalah analisis scoring skala likert, analisis overlay, dan analisis kualitatif. Analis scoring skala likert digunakan untuk mengidentifikasi jenis kegiatan yang ada dan berpotensi ancaman. Analisis overlay digunakan untuk menentukan mintakat inti, mintakat penyangga dan mintakat pengembangan. Sedangkan analisa secara kualitatif digunakan untuk menentukan arahan pengendalian di tiap-tiap mintakat.

Hasil analisa menunjukan bahwa jenis kegiatan dapat dikelompokan menjadi empat berdasarkan potensi tingkat ancaman dan tingkat kepentingannya, yaitu: jenis kegiatan yang memiliki ancaman tinggi dan kepentingan tinggi; jenis kegiatan yang memiliki ancaman tinggi dan kepentingan rendah; jenis kegiatan yang memiliki ancaman rendah dan kepentingan tinggi; dan jenis kegiatan yang memiliki ancaman rendah dan kepentingan rendah. Untuk menentukan mintakat inti, penyangga dan pengembangan jenis kegiatan ini digunakan sebagai faktor penentu selain variable-variabel perlindungan terhadap Benca Cagar Budaya (BCB), yaitu topograpi, radius kesucian pura, dan kebutuhan lahan untuk aktifitas adat. Mintakat inti adalah zona untuk BCB, sehingga jenis kegiatan yang dibolehkan hanya yang berhubungan dengan upacara keagamaan. Mintakat penyangga adalah zona pelindung terhadap zona inti baik secara langsung maupun tidak langsung, sehingga jenis kegiatan yang diijinkan adalah pertanian (sawah, kebun, dan ladang) yang tidak menghalangi pandangan terhadap BCB. Mintakat pengembangan adalah zona manfaat yang diperuntukan bagi masyarakat di sekitar BCB, sehingga jenis kegiatan yang diperbolehkan adalah jenis kegiatan yang memiliki potensi ancaman rendah dan kepentingan tinggi yaitu rumah tunggal, warung, ruko, toko, praktek dokter/bidan, industry kecil, pasar seni, sawah, ladang, kebun, dan atraksi budaya.
\end{abstract}

Kata Kunci: benda/kawasan cagar budaya, zoning regulation, pengendalian pemanfaatan lahan 


\section{Pendahuluan}

Keanekaragaman budaya Indonesia terbentuk melalui perjalanan sejarah yang sangat panjang, mulai dari masa prasejarah hingga sekarang. Perjalanan sejarah tersebut telah memberikan karya yang berupa bangunan-bangunan candi, seni arca, relief, dan sebagainya kepada generasi penerusnya. Menurut Sutaba (1991) Candi Gunung Kawi merupakan salah satu warisan dari nenek moyang yang menggambarkan kehidupan pada zamannya. Karya ini sekaligus menjadi satu bukti keberhasilan nenek moyang membangun hubungan yang harmonis dalam memanfaatkan lingkungan alam di sekitarnya (Ani, 2005). Bukti tersebut disebut sebagai benda cagar budaya, dimana kenyataannya sangat potensial bagi pengembangan pariwisata, terutama pariwisata budaya (Kepala Staf Pengembangan Dinas Pariwisata Kabupaten Gianyar, 2010). Benda cagar budaya merupakan warisan budaya kebanggaan bangsa yang mampu memperkuat jati diri setiap bangsa Indonesia. Peninggalan benda cagar budaya merupakan sumberdaya budaya yang memiliki makna informasi, estetika simbolis, dan ekonomi sehingga menimbulkan daya tarik bagi wisatawan (Mannon dalam Ardika, 2001), oleh sebab itu pemanfaatannya perlu dilakukan secara hati-hati agar terhindar dari kerusakan lebih lanjut.

Adanya nilai-nilai yang dikandung oleh sebuah BCB, menjadikannya aset yang harus dijaga dan dan dilindungi. Menurut Danisworo (1995), konservasi adalah salah satu usaha untuk pelestarian, yaitu upaya untuk melestarikan, melindungi, serta memanfaatkan sumber daya suatu tempat seperti gedung-gedung tua yang memiliki arti sejarah atau budaya, kawasan dengan kehidupan budaya dan tradisi yang mempunyai arti, kawasan dengan kepadatan penduduk yang ideal, cagar budaya, hutan lindung, dan sebagainya.

Konservasi dengan demikian sebenarnya merupakan upaya preservasi, dengan tetap memanfaatkan kegunaan dari suatu tempat untuk menampung/memberi wadah bagi kegiatan yang sama seperti kegiatan asalnya atau bagi kegiatan yangs sama sekali baru sehingga dapat membiayai sendiri kelangsungan eksistensinya. Dengan kata lain, konservasi suatu BCB merupakan suatu proses daur ulang dari sumber daya tersebut. Budihardjo (1994) berpendapat bahwa upaya preservasi mengandung arti mempertahankan peninggalan arsitektur dan lingkungan tradisional/kuno persis seperti keadaan semula. Karena sifat preservasi yang statis, upaya pelestarian merupakan pula pendekatan konservasi yang dinamis, tidak hanya mencakup bangunannya saja tetapi juga lingkungan (conservation area) dan bahkan kota bersejarah (historic town). Dengan pendekatan konservasi, berbagai kegiatan dapat dilakukan, mulai dari inventarisasi bangunan bersejarah, colonial maupun tradisional, upaya pemugaran (restorasi), rehabilitasi, rekonstruksi, sampai dengan revitalisasi, yaitu memberikan nafas kehidupan baru. Sedangkan Fitch (1982) menggunakan istilah preservasi, yaitu suatu usaha untuk memelihara artefak dalam kondisi fisik yang sama sekali diterima oleh agen pemelihara, tidak ada penambahan atau pengurangan dari nilai estetisnya.

Undang-Undang No. 5 Tahum 1992 tentang Benda Cagar Budaya merupakan salah satu bentuk realisasi perlindungan terhadap benda cagar budaya. Perlindungan terhadap BCB ini secara lebih spesifik diatur dalam pasal 2, yaitu "Perlindungan benda cagar budaya dan situs bertujuan untuk melestarikan dan memanfaatkannya untuk memajukan kebudayaan nasional Indonesia". Ketentuan mengenai tata cara pengelolaan benda cagar budaya dan situs ditetapkan 
dengan Peraturan Pemerintah Nomor 10 Tahun 1993. Dalam pasal 18 ayat 3 dijelaskan bagaimana perlindungan terhap benda cagar budaya itu dilakukan melalui penentuan zona/mintakat, yaitu mintakat inti, mintakat penyangga dan mintakat pengembangan.

Perlindungan terhadap BCB ini juga bisa direalisasikan melalui instrument pengendalian pemanfaatan ruang. Di Indonesia dikenal dua jenis pengendalian pemanfaatan ruang, yaitu sistem regulatory (Zoning Regulation) dan pemanfaatan ruang yang proses pengambil keputusannya didasarkan pada pertimbangan lembaga perencanaan yang berwenang untuk masing-masing proposal pembangunan yang diajukan (discretionary system). Zoning merupakan pembagian lingkungan kota ke dalam zona-zona dan menetapkan pengendalian pemanfaatan ruang (ketentuan hukum) yang berbeda-beda (Barnett, 1982). Setiap zona mempunyai aturan yang seragam (guna lahan, intensitas, massa bangunan) dan satu zona dengan zona lainnya bisa berbeda ukuran dan aturan. Dalam zoning aturan ditetapkan terlebih dahulu. Izin pembangunan yang sesuai dengan aturan dapat langsung diterbitkan oleh pejabat berwenang tanpa melalui penilaian (review).

Candi Tebing Gunung Kawi Tampaksiring (GKT) adalah salah satu BCB yang memiliki nilai sejarah dan budaya yang tinggi. Hal terbukti dari terpilihnya kawasan DAS Tukad Pakerisan (lokasi GKT) oleh UNESCO sebagai salah satu warisan budaya dunia dengna nomor C 1194. Situs-situs yang masuk dalam kategori warisan budaya tersebut yaitu Pura Pagulingan, Tirta Empul, Pura Mengening, Candi Tebing Gunung Kawi, Candi Kerobokan, Pura PengukurUkuran, dan Candi Tegallinggah (Deputi Bidang Sejarah dan Purbakala, Kementrian Kebudayaan dan Pariwisata, 2004). GKT merupakan BCB yang berupa kompleks candi peninggalan sejarah dan purbakala yang dipahatkan pada tebing-tebing Daerah Aliran Sungai (DAS) Tukad Pakerisan. Candi Tebing Gunung kawi ini terletak pada suatu gugus situs-situs peninggalan sejarah dan purbakala di kawasan DAS Tukad Pakerisan Gianyar. The World Cultural Heritage Unesco telah menetapkan tiga situs di Bali sebagai nominator Warisan Budaya Dunia (WBD) yakni DAS Tukad Pakerisan (Gianyar), persawahan Jatiluwih (Tabanan) dan Pura Taman Ayun di Mengwi, Kabupaten Badung (Bali Post, edisi minggu 28 Januari 2007)

Sampai saat ini Candi Tebing Gunung Kawi (GKT) telah berhasil memikat banyak wisatawan, baik wisatawan nusantara maupun wisatawan mancanegara. Hal ini karena GKT memang mempunyai keunikan tersendiri dibandingkan dengan kawasan cagar budaya lainnya, yaitu berupa gugusan candi tebing yang tidak ditemukan di tempat lain di Indonesia, kecuali di India Selatann (Parwata, 2004). Keunikan ini tidak hanya pada kelangkaannya, tetapi juga pada pesona arsitekturnya yang menjadikannya daya tarik yang luar biasa bagi para wisatawan untuk berkunjung dan menikmati pesona Situs ini. Selain secara arsitektural, lingkungan alam disekitar GKT menyuguhkan panorama alam yang sangat indah, yang berupa aliran sungai Tukad Pakerisan dengan air yang jernih, sawah terasiring, dan kawasan pertanian subur yang menyuguhkan hijaunya alam (www.purbakalabali.com). Dengan demikian, Gunung Kawi Tampaksiring mempunyai karisma historik yang kuat dan mempunyai pemandangan alam yang indah yang sangat jarang ditemukan pada tempat lain (Runtut, 2010). Selain itu di kawasan GKT ini juga terdapat pura Gunung Kawi yang merupakan salah satu Pura Dang Kayangan yang ada di Bali (Bagian Kesra Pemda Gianyar, 2008). 
Meskipun ditetapkan sebagai warisan budaya dunia (WBD), dua dari tiga kawasan yang bernilai sejarah dan budaya tersebut, yakni Jatiluwih dan DAS Tukad Pekerisan kini dikejar oleh maraknya kafe, restoran, vila dan fasilitas pariwisata lainnya (Bali Post, edisi minggu 28 Januari 2007). DAS Tukad Pakerisan merupakan kawasan yang memanjang dari utara hingga selatan dengan luas sekitar $20 \mathrm{~km}$ di daerah Kabupaten Gianyar yang mempunyai sumber daya alam yang potensial dipilih menjadi hunian dan komunitas (Hasil wawancara dengan bendesa desa pekraman Tamapaksiring, Kapokja Bagian Perlindungan BP3 Bali-Nusra, dan Kepala Bagian Pengembangan Dinas Pariwisata Kabupaten Gianyar). Deretan kawasan persawahan (pertanian) yang subur dengan aliran dari resapan Danau Batur dan Tirta Empul menjadikan kawasan ini sangat menarik karena memiliki sumber daya alam yang memberikan harapan bagi kehidupan. Potensi alam yang bagus menjadikan kawsan ini memiliki daya tarik yang tinggi terhadap perkembangan pariwisata. Hal ini juga berpengaruh terhadap perkembangan infrastruktur permukiman di kawasan tersebut (Hasil wawancara dengan Kapokja Bagian Perlindungan BP3 Bali-Nusra). Dalam RTRW Kabupaten Gianyar, disebutkan bahwa Kawsan di sekitar DAS Tukad Pakerisan diperuntukan sebagai kawasan konservasi dan pertanian. Perkembangan Pariwisata di kawasan DAS Tukad Pakerisan telah memunculkan multiplier effect terhadap penggunaan lahan. Kawasan yang diperuntukan sebagai kawasan pertanianpun mulai diubah fungsi menjadi lahan permukiman dan perlengkapan sarana dan prasarana pendukungnya (Ani, 2005).

Perkembangan permukiman dan pariwisata di Sekitar Kawasan Candi Tebing Gunung Kawi telah banyak mengeintervensi aktivitas keagamaan yang dilakukan di kawasan tersebut, yang merupakan fungsi utama dari situs GKT (Sumartika dkk, 2000). Sebagai kawasan yang religius, di sepanjang DAS Tukad Pakerisan banyak terdapat peninggalan budaya yang saat ini sepenuhnya dilakukan pemeliharaan oleh masyarakat di sekitarnya. Hanya, pemeliharaan dan pengelolaan yang dilakukan oleh masyarakat tersebut terkadang dilakukan tidak sesuai dengan karakteristik dari peninggalan budaya yang ada(Ani, 2005). Masyarakat setempat biasannya mengelola kawasan hanya mengikuti perkembangan pariwisata, seperti penyediaan sarana dan prasarana pariwisata yang hanya diperuntukan bagi pengunjung, tanpa melihat pengaruhnya terhadap keberadaan BCB, dan aktifitas yang ada di situs tersebut (Bali post, 21 desember 2008). Selain mengganggu aktifitas keagamaan, perkembangan permukiman yang tidak terkendali bisa mendesak keberadaan situs, karena keberadaan situs kalah dominan dibandingkan dengan permukiman (Sumartika dkk, 2000). Dominasi permukiman ini tidak hanya terlihat dari intensitas bangunannya, tetapi juga pada aktifitas yang dimunculkan. Aktifitas rumah tangga bukan merupakan aktifitas yang mendukung keberadaan situs GKT, sehingga hal-hal tersebut dikhawatirkan bisa menggangu keberadaan dan fungsi situs, selain itu juga bisa memunculkan presenden negatif terhadap perkembangan pariwisata selanjutnya (Hasil wawancara dengan Kapokja Perlindungan dan Pelestarian BP3 Purbakala Bali-Nusra).

Besarnya pengaruh yang dimunculkan akibat perkembangan permukiman dan pariwisata di kawasan GKT seharusnya menjadi perhatian bagi pemerintah Kabupaten Gianyar. Pengendalian pemanfaatan ruang seharusnya sudah dilakukan untuk mencegah semakin banyaknya konversi lahan yang terjadi di kawasan GKT yang berdampak pada terganggunya eksistensi dari situs tersebut. Zoning Regulation adalah salah satu instrument pengendalian pemanfaatan ruang yang bisa digunakan untuk mengendalikan pemanfaatan ruang di kawasan 
situs GKT. Instrumen ini bisa digunakan untuk mengatur tentang kegiatan dan penggunaan lahan, intensitas pemanfaatan ruang, tata masa bangunan, dan prasarana di kawasan GKT. Penelitian ini berupaya merumuskan prinsip-prinsip Zoning Regulation untuk mengatur penggunaan lahan di sekitar kawasan GKT.

\section{Rumusan Masalah}

Benda Cagar Budaya Candi Tebing Gunung Kawi merupakan salah satu BCB yang memiliki nilai sejarah dan kebudayaan dengan potensi wisata yang sangat besar. Selain potensi sejarah dan budaya, situs ini juga memiliki kawasan ekologi yang sangat bagus. Besarnya potensi yang dimiliki oleh situs ini mengakibatkan pesatnya perkembangan pariwisata di Kawasan GKT. Hal ini berdampak pada perkembangan permukiman. Terutama jenis kegiatan pendukung pariwisata seperti kios-kios penjualan hasil kerajian penduduk setempat. Perkembangan pariwisata telah mengakibatkan pesatnya pertumbuhan permukiman sehingga banyak terjadi konversi lahan di Kawasan GKT. Permukiman ini sangat berpengaruh terhadap eksistensi cagar budaya Candi Tebing Gunung Kawi, karena pesatnya perkembangan permukiman bisa mendesak dominasi BCB Candi Tebing Gunung Kawi.

Berdasarkan rumusan masalah tersebut, pertanyaan penelitian ini adalah apa saja potensi ancaman atau gangguan terhadap situs cagar budaya Candi Tebing Gunung Kawi Tampaksiring?

\section{Metode Penelitian}

Penelitian ini dilakukan di Desa Tampaksiring Kecamatan Tampaksiring Kabupaten Gianyar dengan objek penelitian adalah Candi Tebing Gunung Kawi Tampaksiring. Penelitian ini menggunakan pendekatan kualitatif yang bersifat deskriptif dan preskriptif. Jenis penelitian ini adalah deskriptif dengan model penelitian studi kasus (case study). Tujuan penelitian deskriptif adalah untuk membuat deskripsi secara sistematis, faktual dan akurat mengenai fakta-fakta dan sifat-sifat populasi atau daerah tertentu. Fakta-fakta yang ingin diketahui adalah identifikasi pemanfaatan lahan di sekitar kawasan cagar budaya di wilayah studi, membandingkan karaktersitik pemanfaatan lahan di wilayah studi dengan karakterstik pemanfaatan lahan kawasan cagar budaya, dan undang-undang/aturan daerah/setempat yang mengatur tentang kawasan cagar budaya di wilayah studi. Dari paparan tersebut maka akan diketahui bagaimana kondisi (potensi dan permasalahan) yang terjadi di wilayah studi. Adapun metode analisis yang digunakan dalam penelitian ini antara lain:

1. Metode analisis deskriptif-kualitatif yaitu analisis untuk mengelola dan menafsirkan data yang diperoleh dan mengelompokkannya sehingga dapat menggambarkan keadaan dan permasalahan yang sebenarnya pada obyek yang dikaji. Metode analisis ini digunakan untuk mendeskripsikan dan mengidentifikasi jenis kegiatan yang ada dan berpotensi ancaman terhadap BCB Candi Tebing Gunung Kawi Tampaksiring.

2. Metode analisis deskriptif-komparatif untuk membandingkan jenis kegiatan (memiliki kepentingan tinggi dan memiliki ancaman yang rendah terhadap keberadaan BCB) yang ada di wilayah studi terhadap ketentuan dan standard perlindungan kawasan cagar. Implementasi konsep perlindungan kawasan cagar budaya di luar wilayah penelitian dengan perumusan arahan pengendalian kawasan cagar budaya yang ditawarkan oleh stakeholder untuk menyelesaikan permasalahan di wilayah studi ini merupakan 
langkah yang lebih efektif untuk memecahkan persoalan potensi ancaman terhadap BCB Candi Tebing Gunung Kawi Tampaksiring.

Untuk mendukung metode analisis diatas, maka diperlukan teknik analisis yang digunakan untuk merumuskan aturan pengendalian kawsan cagar budaya Candi Tebing Gunung Kawi Tampaksiring. Teknik analisis yang digunakan untuk mencapai tujuan dan sasaran tersebut adalah analisis skoring dan analisis data kualitatif secara union. Kedua teknik analisis ini dapat digunakan untuk memecahkan permasalahan yang dijabarkan melalui sasaran-sasaran yang berbeda. Dengan demikian ada tiga tahap utama yang dilakukan dalam penelitian ini, yaitu tahap identifikasi jenis kegiatan yang ada dan berpotensi ancaman di kawsan $\mathrm{BCB}$, tahap perumusan mintakat/zonasi kawasan BCB, dan tahap penyusunan aturan di setiap zonasi kawasan BCB.

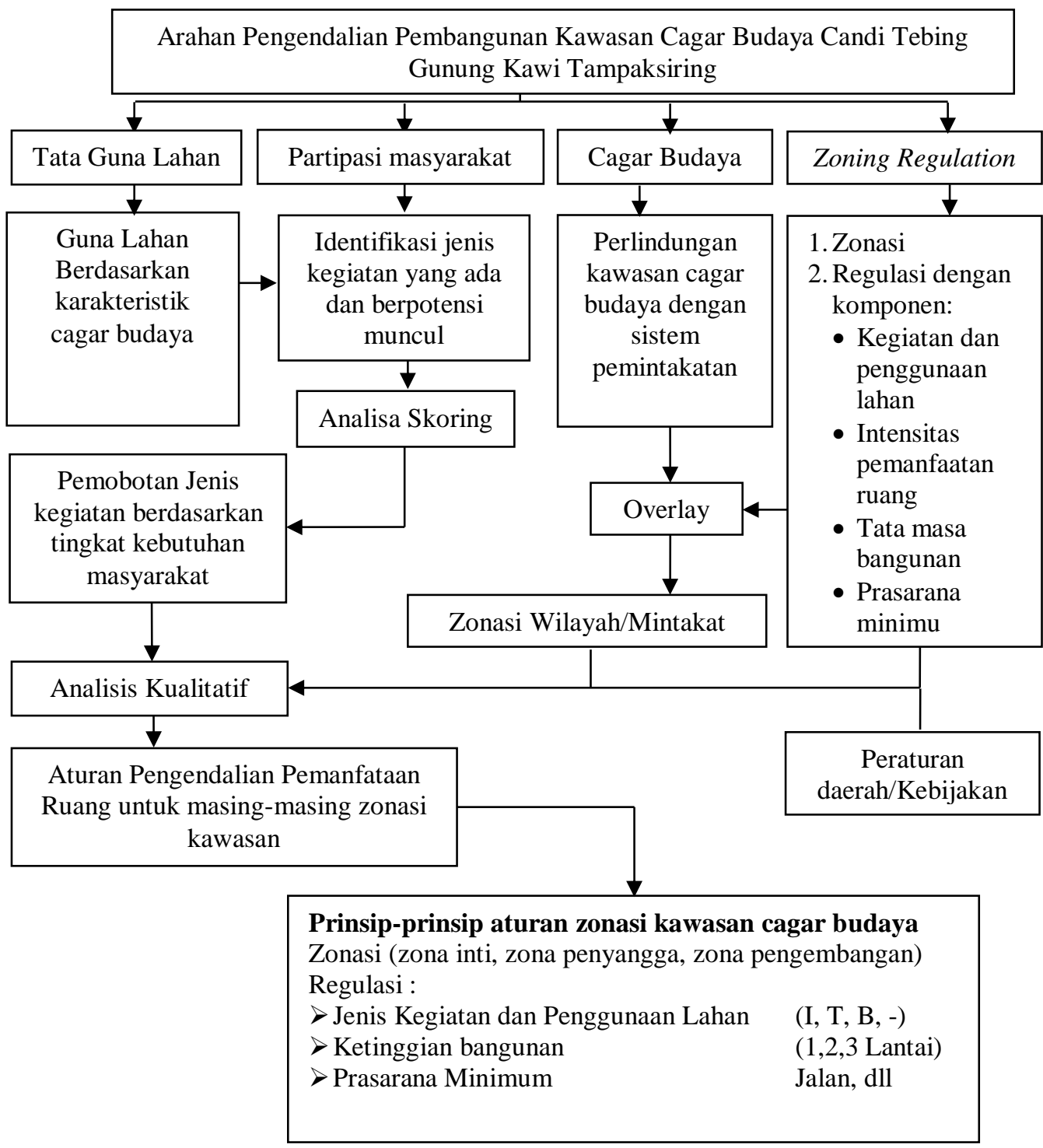

Gambar 1

Kerangka Analisis 


\section{Hasil dan Pembahasan}

\subsection{Identifikasi Jenis Kegiatan yang Ada dan Berpotensi Ancaman Di Kawsan Cagar Budaya Candi Tebing Gunung Kawi}

Pembobotan tingkat kepentingan jenis kegiatan dilakukan dengan analisa scoring skala likert. Sebelum dilakukan analisa, jenis kegiatan yang telah teridentifikasi terlebih dahulu ditabulasikan, yang kemudian dimasukan sebagai input dalam kuisioner berikutnya, untuk ditanyakan kembali ke responden. Hasil kusioner yang kedua merupakan gambaran jenis kegiatan yang diperoleh dari preverensi masyarakat. Dengan melakukan wawancara secara terstruktur melalui kuisioner data tingkat kepentinganya masing-masing jenis kegiatan dapat diperoleh. Data tersebut menunjukan penilaian masyarakat terhadap jenis kegiatan yang telah diidentifikasi sebelumnya. Penilaian tersebut dilakukan dengan cara menilai tingkat kepentingan (sangat penting, penting, tidak penting, sangat penting) dari masing-masing jenis kegiatann yang ada dan berpotensi muncul di Kawasan Cagar Budaya Candi Tebing Gunung Kawi Tampaksiring.

Data tersebut kemudian dibobotkan dengan melakukan analisa scoring skala likert. Sehingga dari keseluruhan jenis kegiatan yang ada di Desa Tampaksiring, jenis kegiatan yang ada dan berpotensi muncul dengan tingkat kepentingan masyarakat terhadap jenis kegiatan tersebut digambarkan oleh tabel 1. berikut.

Tabel 1.

Pembobotan Tingkat Kepentingan/Kebutuhan Masyarakat Desa Tampaksiring Terhadap Jenis Kegiatan yang Ada dan Berpotensi Muncul di Desa Tampaksiring

\begin{tabular}{|c|c|c|c|c|c|c|c|c|c|}
\hline \multirow[t]{2}{*}{ Fungsi Lahan } & \multirow[t]{2}{*}{ Jenis Kegiatan } & \multirow[t]{2}{*}{$\begin{array}{c}\text { Jumlah/ } \\
\text { Bobot }\end{array}$} & \multicolumn{5}{|c|}{$\begin{array}{l}\text { Kepentingan } \\
\text { Masyarakat }\end{array}$} & \multirow[t]{2}{*}{ Total } & \multirow[t]{2}{*}{ Pembobotan } \\
\hline & & & $\mathbf{1}$ & 2 & 3 & 4 & 5 & & \\
\hline \multirow[t]{2}{*}{ Permukiman } & \multirow[t]{2}{*}{ Rumah Tunggal } & Jumlah & 0 & 0 & 0 & 0 & 7 & 7 & \multirow[t]{2}{*}{5.00} \\
\hline & & Bobot & 0 & 0 & 0 & 0 & 35 & 35 & \\
\hline \multirow{10}{*}{$\begin{array}{l}\text { Perdagangan } \\
\text { dan Jasa }\end{array}$} & \multirow[t]{2}{*}{ Warung } & Jumlah & 0 & 0 & 0 & 4 & 3 & 7 & \multirow[t]{2}{*}{4.43} \\
\hline & & Bobot & 0 & 0 & 0 & 16 & 15 & 31 & \\
\hline & \multirow[t]{2}{*}{ Toko } & Jumlah & 0 & 0 & 0 & 4 & 3 & 7 & \multirow[t]{2}{*}{4.42} \\
\hline & & Bobot & 0 & 0 & 0 & 16 & 15 & 31 & \\
\hline & \multirow[t]{2}{*}{ Ruko } & Jumlah & 0 & 0 & 0 & 5 & 2 & 7 & \multirow[t]{2}{*}{4.29} \\
\hline & & Bobot & 0 & 0 & 0 & 20 & 10 & 30 & \\
\hline & \multirow[t]{2}{*}{ Pasar Tradisional } & Jumlah & 0 & 0 & 0 & 1 & 6 & 7 & \multirow[t]{2}{*}{4.86} \\
\hline & & Bobot & 0 & 0 & 0 & 4 & 30 & 34 & \\
\hline & \multirow[t]{2}{*}{ Bengkel } & Jumlah & 0 & 5 & 0 & 2 & 0 & 7 & \multirow[t]{2}{*}{2.57} \\
\hline & & Bobot & 0 & 10 & 0 & 8 & 0 & 18 & \\
\hline \multirow{5}{*}{$\begin{array}{l}\text { Fasilitas } \\
\text { Pendidikan }\end{array}$} & \multirow[t]{2}{*}{ TK } & Jumlah & 0 & 0 & 0 & 3 & 4 & 7 & \multirow[t]{2}{*}{4.57} \\
\hline & & Bobot & 0 & 0 & 0 & 12 & 20 & 32 & \\
\hline & \multirow[t]{2}{*}{ SD } & Jumlah & 0 & 0 & 0 & 3 & 4 & 7 & \multirow[t]{2}{*}{4.57} \\
\hline & & Bobot & 0 & 0 & 0 & 12 & 20 & 32 & \\
\hline & SMP & Jumlah & 0 & 0 & 0 & 3 & 4 & 7 & 4.57 \\
\hline
\end{tabular}




\begin{tabular}{|c|c|c|c|c|c|c|c|c|c|}
\hline \multirow[t]{5}{*}{ Fungsi Lahan } & \multirow[t]{3}{*}{ Jenis Kegiatan } & \multirow[t]{2}{*}{$\begin{array}{c}\text { Jumlah/ } \\
\text { Bobot }\end{array}$} & \multicolumn{5}{|c|}{$\begin{array}{l}\text { Kepentingan } \\
\text { Masyarakat }\end{array}$} & \multirow[t]{2}{*}{ Total } & \multirow[t]{2}{*}{ Pembobotan } \\
\hline & & & 1 & 2 & 3 & 4 & 5 & & \\
\hline & & Bobot & 0 & 0 & 0 & 12 & 20 & 32 & \\
\hline & \multirow[t]{2}{*}{ SMA/MU } & Jumlah & 0 & 0 & 0 & 3 & 4 & 7 & \multirow[t]{2}{*}{4.57} \\
\hline & & Bobot & 0 & 0 & 0 & 12 & 20 & 32 & \\
\hline \multirow{4}{*}{$\begin{array}{l}\text { Fasilitas } \\
\text { Kesehatan }\end{array}$} & \multirow[t]{2}{*}{ Puskesmas } & Jumlah & 0 & 0 & 0 & 3 & 4 & 7 & \multirow[t]{2}{*}{4.57} \\
\hline & & Bobot & 0 & 0 & 0 & 12 & 20 & 32 & \\
\hline & \multirow{2}{*}{$\begin{array}{l}\text { Praktek } \\
\text { Dokter/Bidan }\end{array}$} & Jumlah & 0 & 0 & 0 & 4 & 3 & 7 & \multirow[t]{2}{*}{4.43} \\
\hline & & Bobot & 0 & 0 & 0 & 16 & 15 & 31 & \\
\hline \multirow[t]{2}{*}{ Industri } & \multirow[t]{2}{*}{ Industri Kecil } & Jumlah & 0 & 0 & 0 & 3 & 4 & 7 & \multirow[t]{2}{*}{4.57} \\
\hline & & Bobot & 0 & 0 & 0 & 12 & 20 & 32 & \\
\hline \multirow{12}{*}{$\begin{array}{l}\text { Akomodasi } \\
\text { Wisata dan } \\
\text { Penunjang }\end{array}$} & \multirow[t]{2}{*}{ Hotel } & Jumlah & 0 & 0 & 0 & 4 & 3 & 7 & \multirow[t]{2}{*}{4.43} \\
\hline & & Bobot & 0 & 0 & 0 & 16 & 15 & 31 & \\
\hline & \multirow[t]{2}{*}{ Villa } & Jumlah & 1 & 5 & 0 & 1 & 0 & 7 & \multirow[t]{2}{*}{2.14} \\
\hline & & Bobot & 1 & 10 & 0 & 4 & 0 & 15 & \\
\hline & \multirow[t]{2}{*}{ Penginapan } & Jumlah & 0 & 3 & 0 & 4 & 0 & 7 & \multirow[t]{2}{*}{3.29} \\
\hline & & Bobot & 0 & 6 & 0 & 16 & 0 & 22 & \\
\hline & \multirow[t]{2}{*}{ Restoran } & Jumlah & 0 & 0 & 2 & 5 & 0 & 7 & \multirow[t]{2}{*}{3.57} \\
\hline & & Bobot & 0 & 0 & 6 & 20 & 0 & 26 & \\
\hline & \multirow[t]{2}{*}{ Pasar Seni } & Jumlah & 0 & 0 & 0 & 3 & 4 & 7 & \multirow[t]{2}{*}{4.57} \\
\hline & & Bobot & 0 & 0 & 0 & 12 & 20 & 32 & \\
\hline & Tempat Atraksi & Jumlah & 0 & 0 & 0 & 5 & 2 & 7 & 4.28 \\
\hline & Budaya & Bobot & 0 & 0 & 0 & 20 & 10 & 30 & \\
\hline Pertanian & Sawah & Jumlah & 0 & 0 & 0 & 4 & 3 & 7 & 4.43 \\
\hline & & Bobot & 0 & 0 & 0 & 16 & 15 & 31 & \\
\hline & Ladang & Jumlah & 0 & 0 & 0 & 4 & 3 & 7 & 4.43 \\
\hline & & Bobot & 0 & 0 & 0 & 16 & 15 & 31 & \\
\hline & Kebun & Jumlah & 0 & 0 & 0 & 4 & 3 & 7 & 4.43 \\
\hline & & Bobot & 0 & 0 & 0 & 16 & 15 & 31 & \\
\hline Pemerintahan & Kantor Kecamatan & Jumlah & 0 & 1 & 0 & 5 & 1 & 7 & 4.00 \\
\hline dan Pertahanan & & Bobot & 0 & 2 & 0 & 20 & 5 & 27 & \\
\hline Keamanan & Kantor Kelurahan & Jumlah & 0 & 1 & 0 & 5 & 1 & 7 & 4.00 \\
\hline & & Bobot & 0 & 2 & 0 & 20 & 5 & 27 & \\
\hline & & otal & & & & & & & 100.57 \\
\hline & Rat: & ata Total & & & & & & & 4.19 \\
\hline
\end{tabular}

Sumber: Hasil Analisa 2010

Dari hasil perhitungan bobot tersebut maka diketahui bahwa rata-rata nilai indeks skornya adalah sebesar 4.19. Ini berarti bahwa jenis kegiatan yang nilainya di atas 4.19 adalah jenis kegiatan yang dinilai penting oleh masyarakat sedangkan yang nilainya dibawah 4.19 adalah jenis kegiatan yang dianggap kurang penting oleh masyarakat. Dan semakin besar nilai 
indeks skornya, menunjukan bahwa jenis kegiatan tersebut semakin penting atau semakin dibutuhkan oleh masyarakat Desa Tampaksiring.

Berikut adalah jenis kegiatan dan penggunaan lahan yang memiliki nilai indeks lebih besar dari nilai indeks rata-rata:

1. Rumah tunggal

Ruma tunggal masuk kedalam kategori jenis kegiatan dan penggunaan lahan yang dianggap penting oleh masyarakat karena memiliki nilai indeks sebesar $5.00>4.19$. Hal ini menunjukan bahwa rumah tunggal ini dianggap penting oleh masyarakat Desa Tampaksiring

2. Warung

Warung masuk kedalam kategori jenis kegiatan dan penggunaan lahan yang dianggap penting oleh masyarakat karena memiliki nilai indeks sebesar $4.43>4.19$. Hal ini menunjukan bahwa warung ini dianggap penting oleh masyarakat Desa Tampaksiring

3. Toko

Toko masuk kedalam kategori jenis kegiatan dan penggunaan lahan yang dianggap penting oleh masyarakat karena memiliki nilai indeks sebesar $4.42<4.19$. Hal ini menunjukan toko ini dianggap penting oleh masyarakat Desa Tampaksiring

4. Ruko

Ruko masuk kedalam kategori jenis kegiatan dan penggunaan lahan yang dianggap penting oleh masyarakat karena memiliki nilai indeks sebesar $4.29>4.19$. Hal ini menunjukan bahwa ruko ini dianggap penting oleh masyarakat Desa Tampaksiring

5. Pasar Tradisional

Pasar Tradisional masuk kedalam kategori jenis kegiatan dan penggunaan lahan yang dianggap penting oleh masyarakat karena memiliki nilai indeks sebesar 4.86 > 4.19. Hal ini menunjukan bahwa pasar tradisional ini dianggap penting oleh masyarakat Desa Tampaksiring

6. Fasilitas Pendidikan (TK, SD, SMP, SMA/MU)

Fasilitas Pendidikan (TK, SD, SMP, SMA/MU) masuk kedalam kategori jenis kegiatan dan penggunaan lahan yang dianggap penting oleh masyarakat karena memiliki nilai indeks sebesar $4.57>4$.19. Hal ini menunjukan Fasilitas Pendidikan ini dianggap penting oleh masyarakat Desa Tampaksiring

7. Puskesmas

Puskesmas masuk kedalam kategori jenis kegiatan dan penggunaan lahan yang dianggap penting oleh masyarakat karena memiliki nilai indeks sebesar $4.57>4.19$. Hal ini menunjukan puskesmas ini dianggap penting oleh masyarakat Desa Tampaksiring

8. Praktek Dokter/Bidan

Prakter dokter/bidan masuk kedalam kategori jenis kegiatan dan penggunaan lahan yang dianggap penting oleh masyarakat karena memiliki nilai indeks sebesar 4.43 > 4.19. Hal ini menunjukan tempat praktek dokter/bidan ini dianggap penting oleh masyarakat Desa Tampaksiring

9. Industri Kecil 
Industri Kecil masuk kedalam kategori jenis kegiatan dan penggunaan lahan yang dianggap penting oleh masyarakat karena memiliki nilai indeks sebesar $4.57>4.19$. Hal ini menunjukan Industri Kecil ini dianggap penting oleh masyarakat Desa Tampaksiring

10. Hotel

Hotel masuk kedalam kategori jenis kegiatan dan penggunaan lahan yang dianggap penting oleh masyarakat karena memiliki nilai indeks sebesar $4.43>4.19$. Hal ini menunjukan hotel ini dianggap penting oleh masyarakat Desa Tampaksiring

11. Pasar Seni

Pasar seni masuk kedalam kategori jenis kegiatan dan penggunaan lahan yang dianggap penting oleh masyarakat karena memiliki nilai indeks sebesar $4.57>4.19$. Hal ini menunjukan pasar seni ini dianggap penting oleh masyarakat Desa Tampaksiring

12. Sawah

Sawah masuk kedalam kategori jenis kegiatan dan penggunaan lahan yang dianggap penting oleh masyarakat karena memiliki nilai indeks sebesar $4.43>4.19$. Hal ini menunjukan sawah ini dianggap penting oleh masyarakat Desa Tampaksiring

13. Ladang

Ladang masuk kedalam kategori jenis kegiatan dan penggunaan lahan yang dianggap penting oleh masyarakat karena memiliki nilai indeks sebesar 4.43> 4.19. Hal ini menunjukan ladang ini dianggap penting oleh masyarakat Desa Tampaksiring

14. Kebun

Kebun masuk kedalam kategori jenis kegiatan dan penggunaan lahan yang dianggap penting oleh masyarakat karena memiliki nilai indeks sebesar $4.43>4.19$. Hal ini menunjukan kebun ini dianggap penting oleh masyarakat Desa Tampaksiring

15. Tempat Atraksi Budaya

Tempat Atraksi Budaya kedalam kategori jenis kegiatan dan penggunaan lahan yang dianggap penting oleh masyarakat karena memiliki nilai indeks sebesar 4.28 > 4.19. Hal ini menunjukan tempat atraksi budaya ini dianggap penting oleh masyarakat Desa Tampaksiring

Sedangkan jenis kegiatan dan penggunaan lahan yang memiliki nilai indeks dibawah nilai indeks rata-rata adalah:

1. Bengkel

Bengkel tidak masuk kedalam kategori jenis kegiatan dan penggunaan lahan yang dianggap penting oleh masyarakat karena memiliki nilai indeks sebesar $2.57<4.19$. Hal ini menunjukan bengkel ini tidak dianggap penting oleh masyarakat Desa Tampaksiring

2. Villa

Villa tidak masuk kedalam kategori jenis kegiatan dan penggunaan lahan yang dianggap penting oleh masyarakat karena memiliki nilai indeks sebesar $2.14<4.19$. Hal ini menunjukan villa ini tidak dianggap penting oleh masyarakat Desa Tampaksiring 


\section{Penginapan}

Penginmapan tidak masuk kedalam kategori jenis kegiatan dan penggunaan lahan yang dianggap penting oleh masyarakat karena memiliki nilai indeks sebesar $3.29<$ 4.19. Hal ini menunjukan penginapan ini tidak dianggap penting oleh masyarakat Desa Tampaksiring

4. Restoran

Restoran tidak masuk kedalam kategori jenis kegiatan dan penggunaan lahan yang dianggap penting oleh masyarakat karena memiliki nilai indeks sebesar $3.57<4.19$. Hal ini menunjukan restoran ini tidak dianggap penting oleh masyarakat Desa Tampaksiring

5. Kantor Kecamatan

Kantor Kecamatan tidak masuk kedalam kategori jenis kegiatan dan penggunaan lahan yang dianggap penting oleh masyarakat karena memiliki nilai indeks sebesar $4.00<4.19$. Hal ini menunjukan kantor kecamatan ini tidak dianggap penting oleh masyarakat Desa Tampaksiring

6. Kantor Kelurahan

Kantor Kelurahan masuk kedalam kategori jenis kegiatan dan penggunaan lahan yang dianggap penting oleh masyarakat karena memiliki nilai indeks sebesar $4.00<$ 4.19. Hal ini menunjukan kantor kelurahan ini tidak dianggap penting oleh masyarakat Desa Tampaksiring

Hasil analisa tersebut menunjukan bahwa ada 15 jenis kegiatan yang dianggap penting oleh masyarakat yaitu: Rumah tunggal, Warung, Ruko, Toko, Pasar Tradisional, Fasilitas Pendidikan (TK, SD, SMP, SMA/MU), Puskesmas, Praktek Dokter/Bidan, Industri Kecil, Hotel, Pasar Seni, Sawah, Ladang, Kebun, dan Tempat Atraksi Budaya karena memiliki nilai indeks lebih besar dari nilai indeks rata-rata. Selain itu juga didapatkan ada 6 jenis kegiatan yang dianggap tidak penting oleh masyarakat, yaitu Bengkel, Restoran, Villa, Penginapan, Kantor Kecamatan, dan Kantor Kelurahan karena memiliki nilai indeks lebih kecil dari nilai indeks rata-rata..

\subsection{Perumusan Mintakat/Zonasi Kawasan Cagar Budaya Candi Tebing Gunung Kawi}

Analisa overlay dilakukan untuk menentukan zonasi/mintakat kawasan cagar budaya Candi Tebing Gunung Kawi. Aplikasi ArcGis, merupakan salah satu alat (tools) yang bisa digunakan untuk melakukan analisa overlay. Analisis overlay dilakukan dengan menggunakan 3 variabel yaitu prinsip perlindungan arkeologi terhadap BCB, tingkat kesucian pura (dari segi religius), dan ketentuan (awig-awig) adat setempat.

Ketentuan (awig-awig) Desa Adat mengatur tentang bagaimana kebutuhan lahan untuk masing-masing BCB. Masing-masing BCB memiliki fungsi sebagai tempat suci, sehingga setiap BCB akan memiliki kebutuhan lahan untuk aktifitas adat maupun agama. Sehingga diperlukan adanya lahan untuk kegiatan upacara keagamaan yang akan dilakukan oleh masyarakat Desa Tampaksiring. Kebutuhan lahan untuk aktifitas adat adalah sebesar radius 1015 meter dari bangunan terluar BCB, kecuali BCB di komplek 1 yang tidak memerlukan lahan disekitarnya karena semua aktifitas bisa dilakukan di dalam BCB itu sendiri (BCB di komplek candi 1). 
Variabel kesucian pura tidak bisa diperoleh secara langsung karena masih memerlukan analisa lebih lanjut. Dalam bhisama PHDI telah dijelaskan bahawa Pura Gunung kawi (komplek candi 1) adalah salah satu pura yang memilik status sebagai Pura Dhang Khayangan dengan radius kesucian pura sejauh $2 \mathrm{~km}$ dari dinding terluar pura. Dalam radius $2 \mathrm{~km}$ ini kemudian bisa dibuat zona yang disesuaikan dengan kondisi fisik dan lingkungannya. Sehinggga untuk mengetahui zona-zona tersebut, dilakukan analisa overlay dengan menggunakan variable topografi dan guna lahan.

Hasil analisa overlay tersebut menunjukan bahwa radius kesucian pura yang sejauh minimal $2 \mathrm{~km}$ bisa dikelompokan menjadi zona permukiman dan pertanian. Dalam bhisama PHDI, disebutkan bahwa pembagian zona-zona yang masuk dalam kawasan radius kesucian pura bisa ditentukan dengan melihat kondisi kawasan (topografi dan guna lahan). Hal inilah yang kemudian menyebabkan pembagian zona untuk kawasan kesucian pura dibagi menjadi dua yaitu zona pertanian dan zona permukiman. Pembagian zona kesucian pura menjadi zona pertanian dan permukiman, dikarenakan kawasan di sekitar BCB cukup homogen, yaitu kawasan lembah dan kawasan datar. Zona permukiman adalah zona di sekitar BCB yang memiliki kemiringan 8-15\%, dengan penggunaan lahan utama adalah permukiman dan pertaniaan lahan basah. Zona pertanian adalah zona yang memiliki kemiringan lahan 15-25\% dan $>40 \%$, sehingga penggunaan lahan utama yang dimungkinkan adalah pertanian baik lahan basah maupun lahan kering. Pembagian zona ini sudah sesuai dengan ketentuan dalam bhisama yang dikeluakan oleh PHDI, yaitu zona pertanian berfungsi sebagai penyangga atau zona yang secara langsung bersentuhan dengan tempat suci, dan zona permukiman yang berfungsi sebagai tempat melakukan aktifitas diluar pertanian yang berkaitan dengan keberadaan tempat suci.

Ketiga variable penentu zonasi/mintakat selanjutnya dianalisis overlay dengan menggunakan Aplikasi ArcGis untuk mengetahu pembagian zonasi yang tepat terhadap Kawasan Cagar Budaya Candi Tebing Gunung Kawi. Hasil analisis bisa dilihat pada gambar 2, dimana zonasi kawasan BCB dibagi kedalam tiga zona, yaitu zona inti, zona penyangga dan zona pengembangan, dengan batas-batas yang tertera seperti pada peta.

Zona I atau zona inti adalah zona BCB yang terdiri dari luasan bangunan BCB dan luasan ruang/lahan yang dibutuhkan untuk keperluan adat dan upacara. Sehingga dengan demikian bentuk zona intinya adalah berupa sel yang tersebar. Zona inti adalah zona yang sangat rawan karena berada pada lahan yang memiliki kemiringan lahann 25-40 \% dan > 40 $\%$. Sehingga sangat berbahaya dan berisiko untuk bencana. Hal ini menyebabkan ada pertimbangkan khusus dalam menyusun zona penyangga yang berfungsi untuk melindungi zona inti dan penentuan jenis kegiatan yang diperbolehkan di zona penyangga dan zona pengembangan. Sehingga jenis kegiatan yang diperbolehkan di zona pengembangan, selain memiliki fungsi yang sesuai dengan BCB juga harus mendukung dalam hal penyerapan air dan sekaligus juga bsia melindungi zona inti.

Zona II atau zona penyangga adalah zona diluar zona inti dengan luas wilayah sebesar $22.87 \mathrm{Ha}$. Fungsi utama zona penyangga adalah sebagai pelindung zona inti, meskipun dalam berbagai teori disebutkan bahwa zona penyangga ini juga bisa difungsikan sebagai daya tarik baru selain BCB. Hal ini dikarenakan secara fisik zona ini berada pada kemiringan rata-rata lebih besar dari $40 \%$. Sehinga memang fungsi utamanya adlalah untuk mencegah terjadinya 
bencana yang bisa menimpa zona inti. Zona inti yang memang terletak pada kemiringan yang sama, harus dikelilingi oleh zona yang memilki fungsi melindungi, sehingga penggunaan lahan utama adalah pertanian (baik lahan basah maupun lahan kering).

Sedangkan zona pengembangan adalah zona diluar zona penyangga yang secara fisik berada pada kemiringan rata-rata $0-15 \%$ dengan penggunaan lahan utama berupa permukiman dan kebun. Zona ini memang memiliki pengaruh yang kecil terhadap BCB, tetapi tidak menutup kemungkinan di zona ini juga perlu diatur bagaimana pengaturan jenis kegiatan yang memiliki potensi ancaman terhadap BCB. Hal ini untuk melindungi BCB baik secara fisik maupun non fisik.

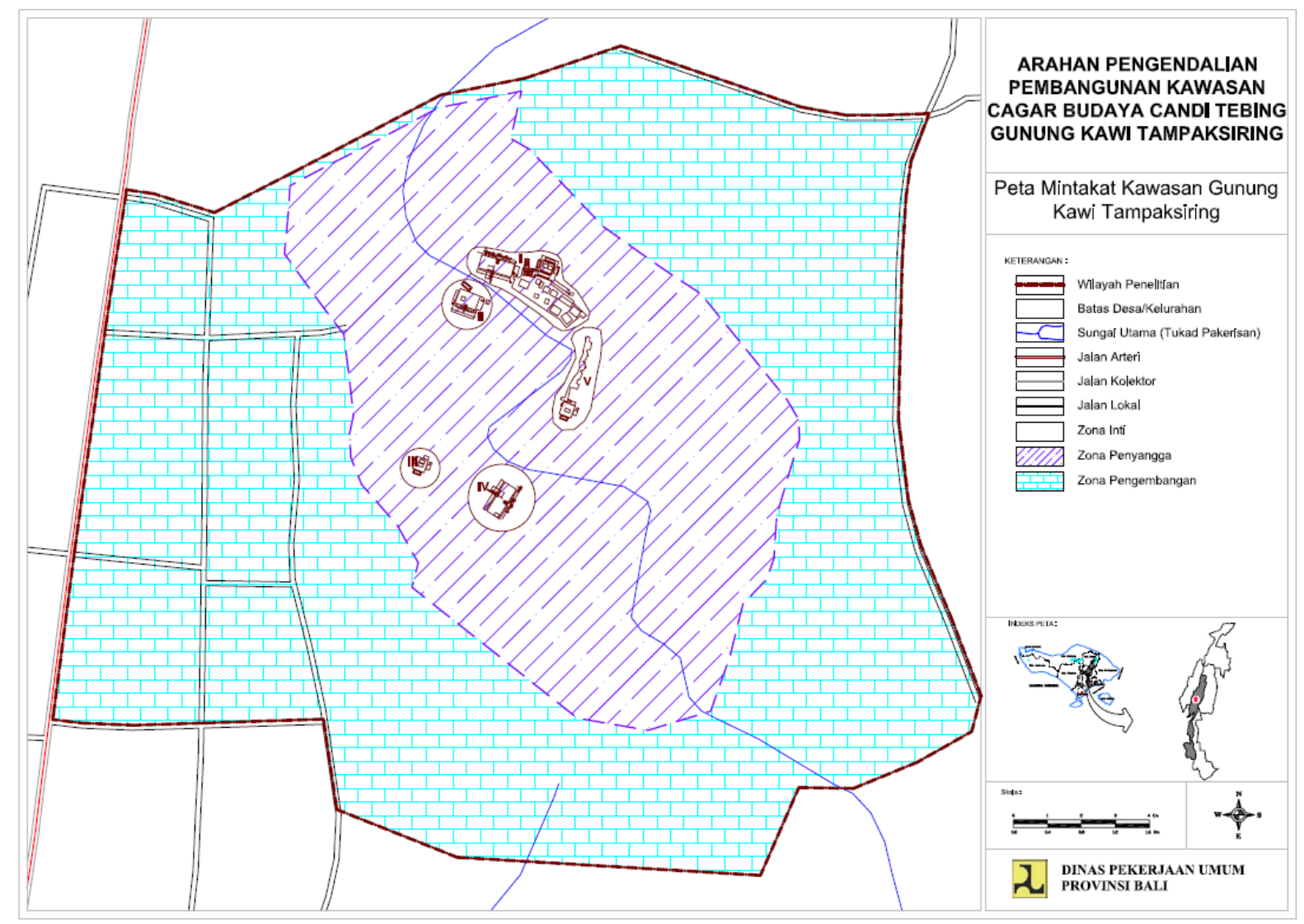

Gambar 2

Peta Hasil Analisa Mintakat Kawasan Cagar Budaya Candi Tebing Gunung Kawi

\subsection{Penyusunan Aturan di Setiap Zonasi Kawasan Cagar Budaya Candi Tebing Gunung Kawi}

Arahan pengendalian pembangunan kawasan cagar budaya Candi Tebing Gunung kawi merupakan hasil penggabungan/kombinasi (union) dari wawancara terstruktur terhadap 7 responden terpilih (Lampiran F). Tiap-tiap responden memiliki pandangan masing-masing sesuai dengan pemahamannya terhadap perlindungan BCB berdasarkan backgroundnya masing-masing. Pengaturan ini dibagi untuk tiap-tiap mintakat/zona yaitu: 


\section{A. Arahan Pengendalian Mintakat/Zona Inti}

Hasil wawancara terhadap Kasi Pemanfaatan dan Perlindungan BP3 Bali Nusra mengenai pengaturan BCB Gunung Kawi menunjukan bahwa prinsip pengaturan untuk masing-masing zona sangat berbeda. Menurut beliau mintakat inti adalah mintakat BCB yang diperuntukan secara khusus untuk BCB itu sendiri. Penentuan mintakat ini dilakukan dengan menggunakan batas fisik dari BCB. Jika tidak ada batas fisik yang barupa tembok atau bangunan terluar dari $\mathrm{BCB}$, maka batas fisik bisa dibuat dengan memberi ruang sejauh 10-20 meter dari bangunan BCB sesuai dengan kebutuhan yang disesuaikan dengan kegiatan yang bisa dilakukan pada BCB tersebut, hal ini juga sesuai degan apa yang tertuang dalam Rencana Induk Arkeologi Trowulan yang menyebutkan bahwa penentuan batas fisik ini bisa disesuaikan dengan kebutuhan dari BCB tersebut. Misalnya jika BCB tersebut juga merupakan tempat suci, maka ketentuannya bukan lagi 50-100 meter seperti yang biasa dilakukan dalam penyusunan zona aman sebuah situs (Gunadi, 1998), tetapi disesuaikan dengan kebutuhan lahan untuk upacara di BCB tersebut (Bhisama PHDI). Ketentuan kebutuhan lahan tersebut bisa disesuaikan dengan ketentuan adat yang diatur dalam awig-awig Desa Pekraman (Desa Adat) yang bersangkutan. Sehingga jenis kegiatan yang diperbolehkan pada zona inti adalah khusus untuk BCB (baik sebagai benda arkeologi maupun sebagai tempat suci).

Menurut Kepala Desa Adat (Bendesa Adat) Tampaksiring jenis kegiatan apapun selain yang berhubungan dengan kegiatan upacara dilarang dilakukan di zona inti untuk menjaga kesucian pura dan menghindari kerusakan-kerusakan yang bisa terjadi zona ini. Salah satu bentuk kegiatan yang terkait dengan tempat suci adalah atraksi tari-tarian yang merupakan bentuk upacara di Pura Gunung Kawi. Hal yang sama juga diungkapkan oleh Bapak Ariadnyana, Kepala Bagian Fisik dan Prasarana yang mengungkapkan bahwa zona inti adalah wilayah yang mencakup keberadaan BCB sehingga segala kegiatan yang ada harus yang sesuai dengan $\mathrm{BCB}$, misalnya pemeliharaan dan perawatan $\mathrm{BCB}$, upacara-upacara keagamaan atau acara-acara adat yang dilakukan di BCB/Pura Gunung Kawi.

Dengan demikian arahan untuk zona inti adalah zona ini diperuntukan untuk bangunan BCB, seluas bangunan BCB tersebut atau radius di sekitar BCB sejauh 10-15 meter (ketentuan awig-awig Desa Pekraman Tampaksiring dan Bhisama PHDI). Zona ini memiliki fungsi sebagai tempat berdirinya artefak atau BCB atau tempat suci. Kegiatan yang diperbolehkan pada zona ini adalah kegiatan yang berupa proses pemeliharaan, perlindungan, dan pengelolaan BCB dan Pura.

Bangunan yang diperbolehkan di mintakat inti atau zona I hanyalah pura atau tempat suci dan semua jenis bangunan yang terkait dengan tempat suci. Hal ini karena, selain sebagai BCB yang memiliki nilai historis, budaya, dan ilmu pengetahuan, $\mathrm{BCB}$ ini juga termasuk dalam kategori tempat suci untuk umat hindu, yaitu pura. Ini didukung juga dalam Babad Bali, yang menjelaskan bahwa pura Gunung Kawi (Lokasi Komplek Candi I) sebagai salah satu pura yang berstatus sebagai pura Dhang Khayangan di Kabupaten Gianyar. Selain karena fungsinya yang terkait terhadap kegiatan keagamaan, bangunan pura juga sangat tidak bertentangan dengan prinsip-prinsip perlindungan BCB Gunung Kawi. Jenis kegiatan yang diperbolehkan juga harus yang berhubungan dengan kegiatan-kegiatan keagamaan ataupun adat yang terkait secara langsung. Jenis kegiatan yang diperbolelehkan adalah atraksi budaya yang secara spesifik 
hanya boleh menampilkan jenis atraksi budaya yang berhubungan dengan acara-acara keagamaan dengan model tarian tradisional atau juga atraksi budaya wayang yang juga terkait secara langsung terhadap kegiatan keagamaan.

Bangunan pura atau tempat suci ini diperbolehkan selain disesuaikan dengan fungsinya, juga sangat bermanfaat terhadap kelestarian BCB tersebut. Karena dengan adanya pura/tempat suci dan kegiatan yang terkait dengan kegiatan keagamaan dan adat maka secara tidak langsung masyarakat juga akan memelihara, merawat, dan menjaga BCB seperti mereka merawat, memelihara, dan menjaga tempat suci mereka, yang merupakan kewajiban yang harus mereka lakukan.

Ketinggian bangunan untuk pura atau tempat suci tentunya ditentukan berdasarkan ketentuan khusus terhadap pura. Jadi untuk ketinggian bangunan tidak perlu diatur secara spesifik, karena sudah ada aturan secara khusus yang mengatur tentang bangunan pura, yang biasanya di ataur dalam ketentuan Bhisama PHDI.

Sementara prasarana minimum yang diperlukan utnuk zona ini adalah listrik (untuk penerangan di tempat suci/BCB), air, toilet, saluran drainase (untuk mencegah kerusakan bangunan karena air) dan jalan setapak (untuk akses ke lokasi BCB) Sementara dengan Kepala Desa Tampaksiring hanya menekankan pada prinsip adat. Sehingga disini perlu dikombinasikan untuk mengakomodasi semua kepentingan yang ada.

\section{B. Arahan Pengendalian Mintakat/Zona Penyangga}

Dalam Rencana Induk Arkeologi dijelaskan bahwa zona penyangga adalah kawasan yang menghadirkan daya tarik baru. Artinya selain memiliki fungsi menjaga zona inti, zona penyangga juga berfungsi sebagai daya tarik baru di kawasan tersebut. Ini juga didukung oleh bagian pengembangan dan pembangunan Dinas Pariwisata Kabupaten Gianyar, yang menjelaskan bahwa zona penyangga bisa menjadi daya tarik di BCB Gunung Kawi, sehingga bisa meningkatkan daya tarik dari wisata budaya Candi Tebing Gunung Kawi. Wisatawan akan mendapatkan pengetahuan sejarah, budaya, dan filosofis, tetapi juga bisa menikmati panorama yang indah yang disajikan dalam zona penyangga. Ini akan semakin menunjang keberadaan wisata budaya di Desa Tampaksiring. Namun pernyataan tersebut tidak senada dengan pernyataan kepala bagian Bagian Fisik dan Prasarana Bapeda Kabupaten Gianyar, beliau menyatakan bahwa fungsi utama zona penyangga adalah melindungi zona inti. Sehingga jenis kegiatan yang diperbolehkan adalah untuk mendukung kelangsungan zona inti. Hal yang sama diungkapkan oleh Kepala Bagian Pemanfaatan dan Perlindungan BP3 Bali Nusra, yang menyatakan bahwa mintakat penyangga adalah mintakat yang diperuntukan untuk melindungi mintakat inti atau menjaga mintakat inti dari interaksi secara langsung terhadap kegiatan yang ada di sekitar BCB.

Sehingga dengan melihat hasil analisa sebelumnya, yaitu kondisi fisik dari zona penyangga dan potensi ancaman dari masing-masing jenis kegiatan, maka dapat disimpulkan bahwa zona penyangga disini lebih berfungsi sebagai zona pelindung secara langsung maupun tidak langsung. Secara langsung bisa melindungi zona inti dari tanah longsor dan cuaca yang buruk, secara tidak langsung bisa menghalangi efek ancaman dari kegiatan di luar zona 
penyangga seperti kegiatan yang manghasilkan limbah, kebisingan, dan aktifitas yang tidak sesuai dengan tema BCB Gunung Kawi Tampaksiring.

Berdasarkan kesimpulan dan penjelasan dari masing-masing responden. Dapat disimpulkan bahwa arahan pengendalian untuk zona penyangga yaitu zona ini berfungsi sebagai pelindung dan pembatas antara zona inti dan zona diluarnya, sehingga jenis kegiatan yang sifatnya kurang terkait secara langsung dengan BCB dilarang. Sehingga jenis kegiatan yang diperbolehkan adalah pertanian, taman, dan juga atraksi budaya. Akan lebih baik jika pada zona ini lebih didominasi oleh taman yang bisa menyerap air dengan baik, dan meminimalkan penggunaan lahan yang kosong, karena berpotensi menyebabkan lahan krtitis.

Ketinggian tamanan yang diijinkan adalah tidak menggangngu jarak pandang terhadap $\mathrm{BCB}$, sehingga disini bisa dikombinasikan antara taman kebun dan pertanian lahan sawah untuk menciptakan keaman pada zona inti dan tetap memberikan ruang terhadap BCB agar tetap bisa dilihat oleh pengunjung. Untuk mendukung jenis kegiatan yang ada di zona ini maka sangat diperlukan adanya sarana dan prasarana. Beberpaa sarana dan prasarana yang diperlukan untuk mendukung zona ini adalah jalan yang tidak diperkeras, listrik, dan saluran drainase (untuk mencegah erosi).

\section{Arahan Pengendalian Mintakat/Zona Pengembangan}

Dalam Rencana Induk Arkeologi Trowulan dijelaskan bahwa mintakat pengembangan adalah mintakat yang diperuntukan untuk tempat beraktifitasnya masyarakat di sekitar BCB. Pada zona ini masyarakat diperbolehkan melakukan kegiatan yang bermanfaat untuk kelangsungan hindup mereka yang pada prinsipnya tidak mengganggu keberadaan BCB. Pernyataan yang sama juga dungkapkan oleh Kepala Desa Tampaksiring, yang menyatakan bahwa BCB Gunung Kawi harus membawa manfaat terhadap masyarakat di sekitar BCB, untuk meningkatkan kepedulian masyarakat terhadap BCB tersebut. Sehingga sangat tepat untuk menyebut zona ini sebagai zona pengembangan yang berarti kawasan untuk dikembangkan, tentunya masih dengan tema yang terkait dengan BCB Gunung Kawi. Hal yang sama juga diungkapkan oleh tokoh-tokoh masyarakat Desa Tampaksiring. Mereka mengungkapkan bahwa, untuk meningkatkan kecintaan dan kepedulian masyarakat terhadap BCB maka diperlukan zona-zona yang memang secar khusus untuk kegiatan masyarakat untuk menunjang kehidupan mereka.

Gunai (1998) mengungkapkan bahwa zona pengembangan adalah zona manfaat, yang bisa digunakan olehg masyarakat untuk aktifitas mereka. Zona ini biasanya digunakan untuk menampung manfaat dari keberadaan BCB. Sehingga tepat sekali kalau zona pengembangan digunkan sebagai kawasan pengembangan aktifitas mayarakat yang memiliki potensi ancaman rendah terhadap BCB.

Zona pengembangan yang disebut juga dengan zona manfaat atau efek dari keberadaan BCB memiliki fungsi yang lebih umum dan mendukung wisata budaya dan aktifitas masyarakat secara lebih luas. Zona III atau zona pengembangan memang diperuntukan untuk aktifitas mayarakat yang ada di sekitar BCB. Akan tetapi tidak semua jenis kegiatan diperbolehkan untuk dilakukan di zona ini. Pada prinsipnya jenis kegiatan yang diperbolehkan adalah jenis kegiatan yang 1) Mendukung kelestarian atau tidak mengganggu eksistensi dari 
BCB 2) Jenis kegiatan yang menunjang pariwisata budaya di Desa Tampaksiring; 3) Bermanfaat bagi masyarakat.

Sehingga arahan pengendalian untuk zona ini yaitu zona ini hanya diperbolehkan jenis kegiatan yang memiliki potensi ancaman rendah dan jenis kepentingan tinggi, jenis kegiatan yang memiliki potensi ancaman rendag dan kepentingan rendah yaitu: 1. Rumah tunggal yang berfungsi sebagai tempat tinggal dengan pola/bentuk rumah tradisional bali, hal ini agar menyesuaikan dengan bentuk rumah yang memang hamper secara keseluruhan adalah rumah tradisional; 2. Kios/Warung yang berfungsi untuk menjual berbagai jenis barang kesenian yang dihasilkan oleh masyarakat Desa Tampaksiring atau makanan khas yang ada di Desa Tampaksiring. Keberadaan Kios/Warung ini sangat penting untuk menunjang wisata budaya di Desa Tampaksiring. 3. Toko yang berfungsi untuk menjual berbagai keperluan dan kebutuhan baik untuk masyarakat setempat maupun untuk wisatawan yang dating ke BCB Gunung Kawi. 4. Industri kecil/kerajinan produk kesenian local merupakan salah satu mata pencaharian utama setelah pertanian di Desa Tampaksiring. Sehingga keberadaan kerajinan ini sangat penting untuk kesejahtraan masyarakat di sana. Selain itu kerajinan ini juga menjadi nilai tambah wisata budaya di Desa Tampaksiring. Dengan adanya sentra kerajinan tradisional ini maka semakin menarik wisatawan, karena wisata budaya yang dijumpai tidak hanya sekedar bangunan yang bernilai sejarah, tetapi juga nilai budaya masyarakat yang ada di Desa Tampaksiring 5. Pasar seni sebagai tempat penjualan hasil karya seni pengrajin di Desa Tampaksiring. Jenis kegiatan ini sangat penting karena menjadi salah satu penghasilan masyarakat Desa tampaksiring. 6. Atraksi budaya menjadi salah satu daya tarik lain yang bisa dibuat dizona ini 7. Pertanian baik pertanian lahan basah maupun pertanian lahan kering sangat penting buat masyarakat, karena merupakan kebutuhan tersebsar dari masyarakat desa tampaksiring. 8. Praktek Dokter/Bidan, sangat penting untuk mendukung keberadaan medis di Kawasan Wisata. Kemudian untuk jenis kegiatan yang memiliki kepentingan tinggi tetapi mengancam, diperbolehkan dengan syarat, yaitu jenis bangunan disesuaikan dengan bangunan di sekitar (bentuk bangunan tradisional), lokasi pada lahan yang datar dan jauh dari BCB, disusahakan memiliki system perserapan air yang baik, memiliki system pengolahan limbah yang baik, dan ketinggian bangunan tidak lebih dari 1 laintai pada zona terluar dari zona pengembangan. Jenis kegiatannya yaitu: Restoran, Hotel, Ruko, Pasar Tradisional, Fasilitas Pendidikan, dan Puskesmas

Pengaturan ketinggian bangunan sebenarnya tidak perlu karena bentuk bangunan yang disarankan adalah bangunan tradisonal (lantai 1) yang rata-rata memiliki ketinggian 8-12 meter. Sehingga ketinggian maksimumnya adalah 12 meter. Untuk mendukung aktifitas yang ada pada zona ini maka sangat diperlukan adanya prasarana, Prasarana minimum yang diperlukan di zona ini adalah jalan (aspal), listrik, saluran drainase, tempat parkir komunal, jaringan telepon, air bersih dan tempat pembuangan sampah. 


\section{Kesimpulan dan Saran}

\subsection{Kesimpulan}

Berdasarkan hasil analisa pada bab sebelumnya maka dapat disimpulkan bahwa ada 21 jenis kegiatan yang teridentifikasi (ada dan berpotensi muncul) di Desa Tampaksiring. 15 jenis kegiatan merupakan jenis kegiatan yang diangap penting oleh masyarakat yaitu rumah tunggal, warung, toko, ruko, pasar tradisional, fasilitas pendidikan (TK, SD, SMP, SMA/MU), puskesmas, praktek dokter/bidan, industry kecil, hotel, pasar seni, sawah, ladang, kebun dan atraksi budaya. sedangkan 6 jenis kegiatan lainnya dianggap tidak penting yaitu bengkel, restoran, villa, penginapan, kantor kecamatan, dan kantor kelurahan. Jenis kegiatan yang memiliki kepentingan tinggi dan rendah dapat dekolmpokan berdasarkan tingkat kepentingannya tersebut dan potensi ancaman terhadap $\mathrm{BCb}$ menjadi jenis kegiatan yang memiliki potensi ancaman tinggi dan kepentingan tinggi, jenis kegiatan yang memiliki potensi ancaman tinggi dan kepentingan rendah, jenis kegiatan yang memiliki potensi ancaman rendah dan kepentingan tinggi dan jenis kegiatan yang memiliki potensi ancaman rendah dan kepentingan rendah.

Jenis kegiatan tersebut mempengaruhi penyusunan mintakat. Dari potensi ancaman terhadap BCB, perlindungan kawasan cagar budaya Candi Tebing Gunung Kawi terbagi menjadi 3 zona atau mintakat, yaitu mintakat inti yaitu zona BCB yang diukur dari dinding terluar BCB atau seluas radius 10-15 meter dari dinding terluar bangunan BCB. Zona Penyangga adalah zona pelindung atau penyangga zona inti, yang terletak di luar zona inti. Zona ini berfungsi untuk melindungai zona inti dari kegiatan masyarakat secara langsung di luar zona penyangga, dan zona pngembangan adalah zona manfaat dari BCB Gunung Kawi. Zona ini berada paling luar yang berfungsi untuk menunjang aktifitas wisata di Desa Tampaksiring.

Pengaturan mintakat dilakukan dengan menggunakan variable jenis kegiatan, ketinggian maksimum, dan prasarana minimu. Sehingga dari hasil analisa kualitatif pengaturan pada zona inti tidak boleh ada jenis kegiatn atau bangunan selain fungsi aslinya yaitu sebagai BCB dan tempat suci. Sehingga jenis kegiatan yang diijinkan adalah jenis kegiatan yang terkait secara langsung terhadap kegiatan keagamaan atau aktifitas-aktifitas yang terkait dengan pemeliharaan, perawatan, dan pengelolaan BCB. Pengaturan di zona penyangga dibatasi pada jenis kegiatan yang sifatnya mendukung untuk perlindungan BCB yaitu pertanian (sawah, ladang, kebun) dan atraksi budaya. Pengaturan di zona pengembangan dibatasi pada jenis kegiatan yang bermanfaat bagi masyarakat dan yang mendukung wisata budaya. sehingga jenis kegiatan yang diperbolehkan adalah rumah, kios, toko, pasar seni, ladang, kebun, dan atraksi budaya.

Pengaturan ketinggian bangunan tidak dilakukan pada zona inti dan penyangga karena jenis kegiatan yang dibolehkan pada zona-zona tersebut todak membutuhkan bangunan untuk mendukung jenis kegiatan yang diperbolehkan pada zona tersebut.

Prasarana minimum untuk zona inti adalah jalan, listrik, saluran air, dan tempat samapah. Prsarana untuk zona penyangga adalah jalan, litrik, dan saluran drainase. Prasarana minimum di zona pengembangan yaitu jalan, parkir, listrik, air bersih, saluran drainase, dan telepon. 


\subsection{Saran}

Dari hasil penelitian ini, maka beberapa rekomendasi yang dapat diberikan adalah sebagai berikut:

1. Arahan pengendalian pembangunan kawasan cagar budaya seharusnya bisa mengakomodasi semua kepentingan yang ada (termasuk local genius) di lokasi BCB.

2. Pelibatan masyarakat secara lebih mendalam sangat diperlukan karena peran serta yang berupa perwakilan (kepala desa) ataupun awig-awig belum mampu mengikat secara kuat keputusan atau hasil studi yang dilakukan.

3. Titik utama permasalahan berada pada masalah ekonomi, hanya saja dalam penelitian ini belum bisa sampai pada masalah manajemen $\mathrm{BCB}$, sehingga sangat dibutuhkan adanya penelitian lanjutan yang bisa menjelaskan lebih jauh keterkaitan antara manajemen BCB, terhadap wisata budaya di Tampaksiring. 


\section{DAFTAR PUSTKA}

Badan Litbang Departemen Pekerjaan Umum. 2000. Kriteria Teknis Penataan Ruang Kawasan Budidaya. Departemen Pekerjaan Umum: Jakarta

Catanese, Anthony J, et. al. 1988. Perencanaan Kota-Edisi Kedua. United State of America: McGraw-Hill, Inc

Direktorat Jendral Penataan Ruang Departemen Pekerjaan Umum. 2006. Konsep Dasar Panduan Penyusunan Peraturan Zonasi Wilayah Perkotaan. Departemen Pekerjaan Umum : Jakarta

Dwiananto, Sigit A. 2005. Zoning Regulation sebagai Perangkat Pengendalian Pembangunan dan Operasionalisasi Rencana Tata Ruang, Paper, disampaikan pada Seminar Nasional Inovasi Praktek Penataan Ruang dalam Desentralisasi Pembangunan, Surabaya

Dwijendra, Ngakan Ketut Acwin. 2009. Arsitektur dan Kebudayaan Bali Kuno. Udayana University Press. Denpasar

Gunadi, 1996. Pemikiran Kembali Tentang Pengertian Situs Arkeologi. Pertemuan Ilmiah Arkeologi VII. Proyek Penelitian Arkeologi Jakarta: Cipanas

Gunadi dan Tri Hatmaji, 1997. Bangunan-Bangunan Indis di Jawa tengah: Tinjauan

Kelestarian dan Pelestariannya. Diskusi Ilmiah Arkeologi VIII. Ikatan Ahli Arkeologi Indonesia, Komisariat D.I. Yogyakarta.

Gunadi, 1998. Archaeological Resource Management in Indonesia: Indo Pacific Prehistory Association Conference: Melaka, Malaysia

Gunadi, 1999a. Pola Pertamanan Situs-Situs Prasejarah di Indonesia. Makalah disampaikan pada Loka Karya Pembuatan Pedoman Pertamanan Benda Cagar Budaya dan Situs, Direktorat Perlindungan dan Pembinaan Peninggalan Sejarah dan Purbakala: Kaliurang

Gunadi, 1999. Wall Painting Conservation in South Sulawesi: A Case Studies on Wooden Panels of Torajann's Traditional House. Ninth Seminar on the Conservation of Asian Cultural Heritage National Research Institute of Cultural Properties: Tokyo, Japan.

Gunadi, 2000. Religious Influences on Indonesian Court Architecture : A Case Studies on Torajan's Traditional Buildings. Seminar on South East Asian Traditional Architecture, SEAMEO Regional Centre For Archaeology and Fine Arts: Bangkok, Thailand.

Gunadi, 2001. Retrospeksi Pengelolaan Sumberdaya Budaya: Satu Studi Kasus Tentang Upaya Pelestarian Sumberdaya Budaya di Makassar. Majalah Dunia Pendidikan, No. 15, 16, dan 17, Kantor Wilayah Departemen Pendidikan dan Kebudayaan Propinsi Sulawesi Selatan.

Jayadinata, Johara T. 1999. Tata Guna Tanah Dalam Perencanaan Pedesaan Perkotaan \& Wilayah. Bandung. Penerbit ITB.

Kaiser, Edward J, David R. Godschalk and F. Stuart Chapin. 1995. Urban Land Use Planning. Urbana and Chicago: University of Illinois Press. 
Kasnowihardjo, H. Gunadi, 2001. Manajemen Sumberdaya Arkeologi. Lembaga Penerbitan Universitas Hasanuddin LEPHAS: Makassar.

Kasnowihardjo, H. Gunadi, 2004. Manajemen Sumberdaya Arkeologi-2. Diterbitkan oleh: Ikatan Ahli Arkeologi Indonesia, Komisariat Daerah Kalimantan

Miles, Matthew B, A. Michael Huberman. Analisis Data Kualitataif. Universitas Indonesia: Jakarta

Parwata, I Wayan. 2004. Dinamika Permukiman Perdesaaan pada Masyarakat Bali. Denpasar

Singarimbun, Masri, dkk. 1989. Metode Penelitian Survei. Lembaga Penelitian, Pendidikan, dan Penerangan Ekonomi dan Sosial: Yogyakarta

Sugiyono, 2009. Metodologi Penelitian Kuantitatif, Kualitatif, dan R\&D. Alfabeta: Bandung

Sunarto, Edy. 2008. Perlindungan dan Pengembangan Kawasan Budaya, Sebuah Alternatif: Bandung

Zulkaidi, Denny dan Petrus Natalivan. 2005. Zoning Regulation dan Building Code

Dalam Pembangunan Kembali Pasca Gempa dan Tsunami Di Provinsi

Nanggroe Aceh Darussalam. Jurnal PWK, Vol.16/ No.1. Bandung : ITB

Dewi, Myrna Augusta. 2007. Perumusan Prinsip-Prinsip Zoning Regulation untuk

Kegiatan Pertanian di Kota Surabaya. ITS :Surabaya

Kurniawan, Kadek Adi. 2009. Pengaturan Kawasan Tempat Suci Pura Uluwati dengan

Pendekatan Zoning Regulation. ITS. Surabaya

Rifai, Tantra. 2008. Prinsip-Prinsip Zoning Regulation di Daerah Rawan Bencana

Lumpur Lapindo Untuk Kegiatan Perumahan (Suatu Instrumen Untuk

Mitigasi Bencana). ITS. Surabaya

Wulandari, Ayu .2007. Studi Pola Perubahan Pemanfaatan Lahan Perumahan Menjadi

Komersial Di Koridor Kertajaya Surabaya. ITS : Surabaya

Dinas Tata Kota Surabaya. 2003. Penyusunan Regulasi Zoning di Kota Surabaya-

Rancangan Regulasi. Pemerintah Kota Surabaya

Undang-Undang Nomor 26 Tahun 2007 tentang Penataan Ruang

Undang-Undang Nomor 5 Tahun 1992 Tentang Benda Cagar Budaya

Peraturan Pemerintah Nomor 10 Tahun 1993 Tentang Ketentuan Teknis Cagar Budaya

Peraturan Menteri Kebudayaan dan Pariwisata Nomor 49 Tahun 2009 Tentang Pedoman

Pelestarian Benda Cagar Budaya dan Situs

Nominator WBD Dikejar Fasilitas Pariwisata, Bali Post Edisi Minggu 28 Januari 2007

Masyarakat Tetap Semangat Jaga Warisan Leluhur, Bali post, 21 desember 2008

Pelestarian Peninggalan Sejarah dan Purbakala www.purbakalabali.com, 1 Oktober 2009

Revitalisasi Candi Gunung Kawi Tampaksiring Gianyar www.purbakalabali.com, 23 september 2009 